\title{
Identifikasi Entamoeba hystolitica dan Balantidium coli pada Lalat di Pasar Legi Surakarta
}

\author{
Identification of Entamoeba hystolitica and Balantidium coli on \\ flies in the Legi Market of Surakarta
}

\author{
Hani Dwi Lestari, Tri Mulyowati* \\ Program Studi D-IV Analis Kesehatan, Fakultas Ilmu Kesehatan, Universitas Setia Budi \\ Jl. Letjen Sutoyo Mojosongo, Surakarta, Jawa Tengah 57121 \\ *Corresponding author: trimulyowatiusb81@gmail.com
}

\author{
Received: February 28, 2019; Revise: April 15, 2019; Accepted: May 3, 2019 \\ DOI : https://doi.org/10.31001/biomedika.v12i1.426
}

\begin{abstract}
ABSTRAK
Lalat merupakan salah satu serangga yang termasuk ke dalam Ordo Diptera yang kehadirannya dapat mengganggu ketentraman manusia dan sebagai vector mekanik penularan penyakit. Kebiasaan lalat yang menyukai tempat-tempat kotor seperti pasar yang menyebabkan semua bagian tubuh lalat dapat dengan mudah membawa parasit jenis protozoa usus pada tubuhnya seperti Entamoebahistolytica, Entamoeba coli, Giardia lamblia, dan Balatidium coli. Beberapa spesies Lalat mendapat perhatian cukup tinggi di bidang kesehatan. Penyakit-penyakit yang biasanya ditularkan lalat antara lain kolera, diare, disentri, tifus, dan penyakit pencernaan. Penelitian dilakukan di Laboratorium Parasitologi Fakultas Ilmu Kesehatan Universitas Setia Budi, Surakarta. Sampel yang digunakan sebanyak 40 sampel yang terdiri dari 20 sampel Musca domestica dan 20 sampel Chrysomya megachepala. Identifikasi Entamoeba hystolitica dan Balantidium coli pada lalat dilakukan dengan metode sedimentasi yang menggunakan lauratan $\mathrm{NaCl} 0,9 \%$ dan kemudian dilakukan pengamatan secara mikroskopis. Berdasarkan hasil identifikasi Entamoeba hystolitica dan Balantidium coli pada tubuh lalat Muscadomestica danChrysomyamegacephala yang diperoleh di Pasar Legi, Surakarta ditemukan 1 kista Entamoeba histolytica pada Musca domestica dengan prosentase 5\% dan 2 Trofozoit Balantidium coli pada Chrysomya megacephala dengan prosentase $10 \%$.
\end{abstract}

Kata kunci: Entamoeba hystolitica; Balantidium coli; lalat

\section{ABSTRACT}

Flies is one of the insects belonging to the Diptera Order whose presence can disturb human tranquility and as a mechanical vector of disease transmission. The habit of flies that like dirty places like markets that cause all the body parts of flies can easily carry intestinal protozoa type parasites on the body such as Entamoebahistolytica, Entamoeba coli, Giardia lamblia, and Balatidium coli. Some species of Flies receive considerable attention in health. Diseases that are usually transmitted flies include cholera, diarrhea, dysentery, typhus, and digestive diseases. The research was conducted at Parasitology Laboratory of Faculty of Health Sciences Setia Budi University, Surakarta. The sample used was 40 samples consisting of 20 samples of Muscadomestica and 20 samples of Chrysomya megachepala. Identification of Entamoeba hystolitica, Balantidium coli in flies was performed by 
sedimentation method using $\mathrm{NaCl}$ lauratan $0.9 \%$ and then microscopic observation. Based on identification result of Entamoeba hystolitica dan Balantidium coli on flies Muscadomestica and Chrysomya megacephala obtained in Legi Market, Surakarta found 1 Entamoeba histolytica cyst in Muscadomestica with percentage of 5\% and 2 Trofozoit Balantidium coli at Chrysomya megacephala with percentage $10 \%$.

Keywords: Entamoeba hystolitica; Balantidium coli; flies

\section{PENDAHULUAN}

Infeksi parasit serta penyakitpenyakit yang ditularkan oleh vektor masih menjadi masalah esehatan bagi masyarakat (Pusarawati dkk, 2013).Penyakit infeksi yang disebabkan oleh protozoa banyak ditemui didaerah tropist ermasuk Indonesia. Protozoa merupakan organisme penghuni tempattempat berair seperti selokan, sawah, parit, sungai, waduk, air laut, tanah dan didalam tubuh organisme lain (Irianto, 2009). Lalat adalah salah satu serangga yang termasuk kedalam ordo diptera. Populasinya sangat tinggi hal ini dipengerahui oleh morfologi tubuh lalat yang berukuran kecil, daya reproduksinya tinggi, kemampuan terbang yang jauh, serta siklus hidup pendek (Astuti dan Pradani, 2010).

Kehadiran serangga seperti lalat dapat mengganggu ketentraman manusia, dan sebagai vector mekanik penularan penyakit (Natadisastra dan Agoes, 2009). Lalat mudah tercemari agen penyakit baik pada tubuhnya seperti kaki maupun mulut karena lalat berkembang biak pada media yang mengandung agen penyakit seperti feses, sampah, kotoran hewan, dan limbah buangan (Ryani dkk, 2017). Salah satu tempat yang disukai oleh lalat adalah pasar karena pada umumnya sampah basah, kotoran binatang, sisasayuran yang membusuk banyak dijumpai di sana (Sucipto, 2011). Penyakit-penyakit yang biasanya ditularkan lalat antara lain kolera, diare, disentri, tifus, dan penyakit pencernaan (Widodo, 2013).

Berdasarkan latar belakang tersebut, penulis terdorong untuk melakukan penelitian. Identifikasi ptotozoa usus pada lalat untuk mengetahui apakah terdapat protozoa usus pada lalat dipasar legi surakarta serta mengetahui persentase ditemukannya protozoa usus pada lalat dipasar legi surakarta. Penelitian ini dilakukan dapat memberikan manfaat berupa pengetahuan dan informasi tentang bahaya atau dampak dari lalat sebagai vector mekanik dari beberapa penyakit serta mengingatkan masyarakat untuk meningkatkan upaya pencegahan dan menjaga hygiene dan sanitasi.

\section{METODE PENELITIAN}

\section{Alat dan Bahan}

Botol plastic 1,5 Liter, pisau, tabung reaksi, [inset, sentrifuge, obyek glass, deck glass, mikroskop. Nangka, lalat Musca domestica, lalat Chrysomya megacephala, $\mathrm{NaCl}$ 0,9\% dan larutan lugol.

\section{Prosedur Kerja \\ Pengambilan Sampel}

1. Menyediakan botol plastik berukuran 1,5 liter yang telah dipotong pada sekitar 1/3 bagian atasnya. 
2. Potongan botol bagian atas diletakkan terbalik pada botol tersebut sehingga berbentuk seperti corong.

3. Ke dalam botol tersebut dimasukkann angka sebagai umpan bagi lalat.

4. Setelah persiapan selesai, botol tersebut diletakkan di pasar yang sudah ditentukan selama 2 jam (Ishartadiati, 2009).

\section{Identifikasi Mikroskopis}

1. Identifikasi jenis lalat yang akan digunakan sebagai sampel penelitian

2. Sampel lalatdimasukan kedalam tabung reaksi yang sudah berisi $2 \mathrm{ml}$ larutan $\mathrm{NaCl}$ 0,9\%.

3. Tabung reaksi yang berisi lalat tadi di kocok selama 2 menit.

4. Mengeluarkan lalat dari tabung reaksi.
5. Sampel suspensi cucian lalat dicentrifuge dengan kecepatan 3000 rpm selama 5 menit.

6. Membuang bagian atas permukaan supernatan, kemudian mengambil sedimen dan diletakkan diatas obyek glass.

7. Menetesi sedimen dengan larutan lugol sebanyak 1 tetes dan tutup dengan deck glass.

8. Mengamati dibawah mikroskop dengan perbesaran 400x dan 1000x (Ryani dkk, 2017)

\section{Analisis Data}

Data yang didapatkan kemudian dijumlah berdasarkan jenis protozoausus yang didapat pada permukaan tubuh lalat, kemudian dihitung prosentasenya. Perhitungan prosentase sebagai berikut:

$$
\begin{aligned}
& =\frac{\text { Jumlah lalat yang positif terinfeksi protozoa usus }}{\text { Jumlah sampel }} \times 100 \% \\
& =\frac{\text { Jumlah lalat yang negatif terinfeksi protozoa usus }}{\text { Jumlah sampel }} \times 100 \%
\end{aligned}
$$

(Kemenkes, 2012)

\section{HASIL DAN PEMBAHASAN}

Berdasarkan hasil Identifikasi spesies lalat yang tertangkap di pasar Legi surakarta adalah lalat Musca dometica dan Chrysomya megacephala. Lalat Musca domestica memiliki ciri-ciri tubuh bewarna abu-abu tua, memiliki sayap, abdomen bewarna kekuningan, bagian toraks terdapat garis-garis hitam yang sama lebar (Irianto, 2009). Jenis lalat lainya yaitu Chrysomya megachepala juga memiliki ciri-ciri seperti tubuh bewarna hijau kebiruan metalik, terdapat sayap jernih dengan guratan urat-urat yang jelas, thorax bewarna hijau metalik kecoklatan, permukaan tubuh tertutup dengan bulubulu pendek keras dan jarang letaknya, abdomen bewarna hijau metalik mempunyai garis-garis transversal, mata yang berukuran besar bewarna merah gelap (Putri, 2015).

Hasil Identifikasi protozoa usus secara mikroskopis pada lalat Musca domestica dan Chrysomya megacephala yang diperoleh di Pasar Legi Surakarta ditemukan 1 kista Entamoeba histolytica pada Musca domesticayang memiliki ciriciri berbentuk memadat mendekati bulat, memiliki 2 buah inti, terdapat benda kromatoid berbentuk batang (Ideham dan Pusarawati, 2009) dengan persentase 5\% 
dan pada Lalat Chrysomya megachepala ditemukan 2 Trofozoit Balantidium coli dengan ciri-ciri bewarna kelabu-hijau, berbentuk lonjong seperti kantong, terbungkus kulit halus untuk pertahanan, serta mempunyai cilia (Irianto, 2009) dengan prosentase $10 \%$.

Prosentase Muscadomestica yang terinfeksi Entamoeba histolytica

$$
\begin{aligned}
& =\frac{\text { Jumlah Musca domestica yang positif terinfeksi kista Entamoeba histolytica }}{\text { Jumlah sampel }} \times 100 \% \\
& =\frac{1}{20} \times 100 \% \\
& =5 \%
\end{aligned}
$$

Prosentase Chrysomya megachepala yang terinfeksi Balantidium coli

$$
\begin{aligned}
& =\frac{\text { Jumlah Chrusomya megachepala yang positif terinfeksi Trofozoit Balantidium coli }}{\text { Jumlah sampel }} \times 100 \% \\
& =\frac{2}{20} \times 100 \% \\
& =10 \%
\end{aligned}
$$

Hasil Identifikasi, spesies lalat yang tertangkap di pasar legi surakarta adalah lalat Musca domestica dengan ciriciri tubuh bewarna abu-abu tua, memiliki sayap, abdomen bewarna kuning, toraks terdapat garis hitam yang sama lebar (Irianto, 2009). Lalat lain yang tertangkap adalah Chrysomya megachepala dengan ciri tubuh bewarna kebiruan metalik, terdapat sayap jernih dengan guratan urat jelas, mata berukuran besar bewarna merah gelap (Putri, 2015). Ditemukannya kista Entamoeba histolytica dan trofozoit Balantidium coli pada lalat dikarenakan lalat yang menyukai tempat kotor seperti pasar yang menyebabkan semua bagian tubuh lalat dapat dengan mudah membawa parasit pada tubuhnya (Safitri dkk, 2017). Keberadan protozoa usus pada lalat membahayakan kesehatan apabila protozoa tersebut tertelan dan masuk kedalam tubuh melalui perantara makanan atau minuman yang dapat menyebabkan penyakit infeksi saluran pencernaan atau dikenal sebagai disentri amoeba (Irianto, 2009).Pencegahan infeksi oleh protozoa dapat dilakukan dengan meningkatkan Higine dan sanitas perorangan serta menjaga makanan dan minuman tetap bersih, tidak tercemar dengan kista Entamoeba histolitica maupun trofozoit Balantidium coli (Nurhayati, 2010).

\section{KESIMPULAN}

Berdasarkan penelitian yang dilakukan pada 20 sampel Lalat Muscadomestica dan 20 sampel Lalat Chrysomya megachepala yang diperolehdari PasarLegi Surakarta, bahwa samepl ditemukan 1 kista Entamoeba histolytica pada lalat jenis Muscado mestica dan ditemukan 2 trofozoit Balantidium coli pada lalat jenis Chrysomya megacephala. Persentase 
protozoa usus yang ditemukan pada lalat jenis Muscado mesticaadalah 5\% dan persentase protozoa usus yang ditemukan pada lalat jenis Chrysomya megacephala adalah $10 \%$.

\section{DAFTAR PUSTAKA}

Artika, M., Nurhayati., Y. Alioes. 2017. "Hubungan Kebiasaan Mencuci Tangan dan Memotong Kuku dengan Kejadian Giardiasis Asimtomatik”. Jurnal Kesehatan. 6 (1)

Astuti, E.P., dan Firda Yanuar Pradani. 2010. "Pertumbuhan dan Reproduksi Lalat Musca domestica pada berbagai media perkembangbiakan". Aspirator. vol.2. No.1 : 11-16

Ideham, B., dan Pusarawati, S. 2009. Penuntun Praktis Parasitologi Kedokteran. Surabaya : Airlangga University

Irianto, K. 2009. Panduan Praktikum Parasitologi Dasar untuk Paramedis dan Nonmedis. Bandung: Yrama Widya.

Natadisastra, D., dan Agoes, R. 2009. Parasitologi Kedokteran ditinjau dari Organ Tubuh yang diserang. Jakarta: EGC.

Nurhayati. 2010. "Gambaran Infeksi Protozoa Intestinal Pada Anak Binaan Rumah Singgah Amanah Kota Malang". Majalah Kedokteran Andalas. No.1. Vol.34

Pusarawati, S., B. Ideham., Kusmartisnawat., I.S. Tantular., S. Basuki. 2013. Atlas Parasitologi Kedokteran. Jakarta: EGC.
Putri, Y. P. 2015. "Keanekaragaman Spesies Lalat (Diptera) dan Bakteri pada Tubuh Lalat di Tempat Pembuangan Akhir Sampah (TPA) dan Pasar". Jurnal Teknik Lingkungan UNAD 12 (2): 1-11

Ryani, M. H., R. Hestiningsih., M. Hadi. 2017. "Ektoparasit (Protozoa dan Helminthes) pada Lalat di Pasar Johar dan Pasar Peterongan Kota Semarang". Jurnal Kesehatan Masyarakat. Volume. 5. Nomor. 4

Safar, R. 2010. Parasitologi Kedokteran: Protozoologi Helmintologi Entomologi .Bandung: Yrama Widya.

Safitri, V ., P. Hastutiek., Arimbi. 2017. "Identifikasi Bakteri pada Eksoskeleton Lalat di Beberapa Pasar di Surabaya". Jurnal Parasitologi. Vol. 1. No. 1

Sucipto, C. D. 2011. Vektor Penyakit Tropis. Yogyakarta: Gosyen Publishing.

Susanna, D., dan Sembiring, T.U.J. 2011. Entomologi Kedokteran: atropoda penganggu kesehatan dan parasit yang dikandungnya. Jakarta: Universitas Indonesia

Widodo, H. 2013. Parasitologi Kedokteran . Jogjakarta : D-MEDIKA (Anggota IKAPI).

Zanaria, T. M., R. Hidayat., Muhsin., Safarianti., Nurwahyuniati. 2016. Penuntun Praktikum "Protozoa Usus". Aceh : Fakulta Kedokteran Universitas Syiah Kuala

Zulkoni, H. A. 2011. Parasitologi untuk Keperawatan, Kesehatan Masyarakat, dan Teknik Lingkungan. Yogyakarta: Nuha Medika. 